\title{
Genetic NMDA Receptor Deficiency Disrupts Acute and Chronic Effects of Cocaine but not Amphetamine
}

\author{
Amy J Ramsey', Aki Laakso', Michel Cyr ${ }^{1,3}$, Tatyana D Sotnikova', Ali Salahpour', Ivan O Medvedev', \\ Linda A Dykstra ${ }^{2}$, Raul R Gainetdinov' and Marc G Caron*,' \\ 'Department of Cell Biology, Duke University Medical Center, Durham, NC, USA; ${ }^{2}$ Department of Psychology, University of North Carolina at \\ Chapel Hill, Chapel Hill, NC, USA
}

\begin{abstract}
NMDA receptor-mediated glutamate transmission is required for several forms of neuronal plasticity. Its role in the neuronal responses to addictive drugs is an ongoing subject of investigation. We report here that the acute locomotor-stimulating effect of cocaine is absent in NMDA receptor-deficient mice (NRI-KD). In contrast, their acute responses to amphetamine and to direct dopamine receptor agonists are not significantly altered. The striking attenuation of cocaine's acute effects is not likely explained by alterations in the dopaminergic system of NRI-KD mice, since most parameters of pre- and postsynaptic dopamine function are unchanged. Consistent with the behavioral findings, cocaine induces less c-Fos expression in the striatum of these mice, while amphetamine-induced c-Fos expression is intact. Furthermore, chronic cocaine-induced sensitization and conditioned place preference are attenuated and develop more slowly in mutant animals, but amphetamine's effects are not altered significantly. Our results highlight the importance of NMDA receptor-mediated glutamatergic transmission specifically in cocaine actions, and support a hypothesis that cocaine and amphetamine elicit their effects through differential actions on signaling pathways.

Neuropsychopharmacology (2008) 33, 270 I-27I4; doi:I0.1038/sj.npp. I 301663; published online 9 January 2008
\end{abstract}

Keywords: cocaine; amphetamine; dopamine; NMDA receptor; sensitization; addiction

\section{INTRODUCTION}

Cocaine and amphetamine are thought to exert their stimulant and addictive effects by elevating synaptic concentrations of monoamines, particularly dopamine, in brain reward areas. Cocaine elevates dopamine by preventing the reuptake and clearance of the stimulated release of dopamine, whereas amphetamine elevates dopamine not only by acting as a dopamine transporter substrate and competitively inhibiting dopamine transport, but also by dissipating the vesicular storage and reversing plasma membrane monoamine transporters, thus releasing the vesicular pool of stored dopamine into the synapse (Amara and Kuhar, 1993; Jones et al, 1998; Sulzer et al, 2005).

Although these psychostimulants do not act directly on glutamate receptors, their physiological actions are influenced by glutamatergic transmission. This is due in part to

*Correspondence: Dr MG Caron, Department of Cell Biology, Duke University Medical Center, Box 3287, Room 48I CARL Building, Research Drive, Durham, NC 27710, USA,

Tel: + I 9196845433 , Fax: + I 9196818641 ,

E-mail: caron002@mc.duke.edu

${ }^{3}$ Current address: Neuroscience Research Group, Universite du Quebec a Trois-Rivieres, CP500, Trois-Rivieres, QC, Canada G9A $5 \mathrm{H} 7$.

Received 13 July 2007; revised 2 November 2007; accepted 24 November 2007 the convergence and integration of dopaminergic and glutamatergic signals within neurons of the striatum and nucleus accumbens, brain regions that regulate locomotion and motivated behaviors. Pharmacological disruption of glutamate receptor signaling has been reported to modify the acute behavioral effects of cocaine (Karler and Calder, 1992; Kenny and Markou, 2004). Furthermore, glutamatemediated plasticity is implicated in the development of addiction (Thomas et al, 2001; Nestler, 2001; Hyman and Malenka, 2001; White, 2002). NMDA-type glutamate receptors are crucial components mediating the neuronal plasticity that accompanies spatial learning and memory (Tang et al, 1999; Shimizu et al, 2000). Common molecular components, including the NMDA receptor, might also determine the lasting changes in the brain's reward system that cause addiction. Recent studies have investigated the impact of psychostimulant exposure on the electrophysiological properties of striatal neurons and the number of AMPA-type glutamate receptors that are trafficked to and from striatal synapses (Thomas et al, 2001; Beurrier and Malenka, 2002). NMDA receptors can potentially regulate the number of AMPA receptors at the synapse through a calcium signaling cascade that controls the phosphorylation of the GluR1 subunit of AMPA receptors by protein kinase A (Ehlers, 2000, Beattie et al, 2000; Snyder et al, 2005).

Early neuronal plasticity from psychostimulant exposure can be manifested behaviorally as sensitization, where each 
consecutive exposure to the reinforcing drug leads to an enhanced response such as locomotor activation in rodents (Segal and Mandell, 1974; Post and Rose, 1976). This altered state of responsiveness involves long-lasting changes in gene expression, electrophysiological properties, and even morphology of striatal medium spiny neurons (Yao et al, 2004; Thomas et al, 2001; Nestler, 2001; Bibb et al, 2001; Robinson and Kolb, 1997; Koob et al, 1998). Several groups have reported disrupted sensitization to psychostimulants and dopaminergic agonists using pharmacological tools to block NMDA receptor function (Li et al, 1999; Haracz et al, 1995; Kalivas and Alesdatter, 1993; Stewart and Druhan, 1993; Wolf and Jeziorski, 1993; Karler et al, 1989); however, variations in the timing and context of NMDA antagonist administration may affect different aspects of the biological process underlying sensitization (Tzschentke and Schmidt, 1998; Ranaldi et al, 2000).

To clarify the role of NMDA receptor signaling in different psychostimulant actions, we studied the effects of cocaine and amphetamine in mice with reduced expression of the essential NR1 subunit of the NMDA receptor (Mohn et al, 1999) caused by hypomorphic mutation of Grin1. The NR1 knockdown mice (NR1-KD) survive into adulthood and have a phenotype resembling pharmacological blockade of NMDA receptors. These mice have $90 \%$ decrease in NMDA receptor expression and display increased locomotor and stereotypic activity and deficits in social interactions, while showing normal extracellular levels, storage, and metabolism of the monoamines dopamine and serotonin. In this study we found that the acute effects of cocaine were markedly diminished in NR1-KD mice, whereas the response to amphetamine was unaltered. Repeated cocaine administration led to a delayed development of sensitization, and the expression of sensitization was less pronounced than what is seen in wild-type mice. However, the rewarding properties of cocaine and amphetamine were preserved in NMDA receptor-deficient mice.

\section{MATERIALS AND METHODS}

\section{Animals}

All studies were conducted with an approved protocol from the Duke University Institutional Animal Care and Use Committee and in compliance with NIH guidelines for the care and use of experimental animals. The generation of NR1-KD mice has been described previously (Mohn et al, 1999). Experimental animals were derived by intercrossing C57B16/129Ola/DBA2 mice that were heterozygous for the altered Grin1 allele. Animals were housed 4-5/cage, maintained under standard lab conditions $(12 \mathrm{~h}$ light/dark cycle) with food and water provided ad libitum, and tested at 10-16 weeks of age. Wild-type and mutant groups were matched for age and gender in all experiments, and all drugs and doses were tested in drug-naive animals.

\section{Western Blot}

Brain tissue from animals euthanized by cervical dislocation was prepared by rapid postmortem dissection and freezing. Midbrain regions were dissected by isolating a $1 \mathrm{~mm}$ coronal section at -3 bregma and removing the $1 \mathrm{~mm}^{3}$ region from each hemisphere where the substantia nigra and ventral tegmental areas are located. Striatum, hippocampus, prefrontal cortex, and midbrain were homogenized in $50 \mathrm{mM}$ Tris (pH 7.4), $150 \mathrm{mM} \mathrm{NaCl}, 2 \%$ SDS, $1 \mathrm{mM}$ EDTA and protease inhibitor cocktail (Complete Mini, Roche, Mannheim, Germany). 20-40 $\mu$ g of protein extracts were resolved with a denaturing $10 \%$ acrylamide gel and transferred to nitrocellulose membranes before incubating with the appropriate antibodies. Blots were incubated overnight at $4{ }^{\circ} \mathrm{C}$ with primary antibodies against NR1, NR2A, NR2B, GluR1, GluR2/3 (Upstate Biotechnology, Lake Placid, NY), or actin (Chemicon, Temecula, CA). Following incubation with peroxidase-conjugated secondary antibodies, protein levels were detected with chemiluminescence (SuperSignal West Pico, Pierce, Rockford, IL) and compared by densitometry using Scion Image (Scion Corporation, Frederick, MD).

\section{Locomotor Activity Measurements}

Locomotion was evaluated in an automated Omnitech Digiscan apparatus (AccuScan Instruments, Columbus, $\mathrm{OH}$ ) under illuminated conditions as described previously (Gainetdinov et al, 1999). Individual activity data were collected at $5 \mathrm{~min}$ intervals. Locomotor activity was measured as the total distance traveled. Before drug administration, mice were habituated to the activity monitor for $60 \mathrm{~min}$. Amphetamine, cocaine, and quinpirole were dissolved in saline, SKF-81297 was dissolved in distilled water, and all drugs were administered intraperitoneally (i.p.) in a volume of $10 \mathrm{ml} / \mathrm{kg}$. Control animals received a corresponding volume of saline. All drugs were obtained from Sigma (St Louis, MO).

\section{In Vivo Microdialysis}

Mice were anesthetized with chloral hydrate $(400 \mathrm{mg} / \mathrm{kg}$, i.p.) and placed in a stereotaxic frame. Dialysis probes (2 $\mathrm{mm}$ membrane length, $0.24 \mathrm{~mm}$ o.d., Cuprophane, $6 \mathrm{kDa}$ cutoff, CMA-11; CMA/Microdialysis, Solna, Sweden) were implanted in the right striatum. The stereotaxic coordinates for implantation of microdialysis probes were $0.0 \mathrm{~mm} \mathrm{AP}$, $-4.4 \mathrm{~mm} \mathrm{DV}$, L2.5 relative to bregma. After surgery, animals were returned to their home cages with free access to food and water. At least $24 \mathrm{~h}$ after surgery, the dialysis probe was connected to a syringe pump and perfused at $1 \mu \mathrm{l} / \mathrm{min}$ with artificial cerebrospinal fluid $(147 \mathrm{mM} \mathrm{NaCl}$, $2.7 \mathrm{mM} \mathrm{KCl}, 1.2 \mathrm{mM} \mathrm{CaCl}_{2}, 0.85 \mathrm{mM} \mathrm{MgCl}$ ) (CMA/Microdialysis). After an equilibration period of $1 \mathrm{~h}$, the perfusates were collected every $20 \mathrm{~min}$. At least four control samples were taken before amphetamine, cocaine, or saline was administered i.p. Data are presented as a percentage of the basal levels (as mean \pm SEM). Perfusate samples were assayed for dopamine with the use of HPLC with electrochemical detection as described (Jones et al, 1998; Gainetdinov et al, 1999).

\section{Radioligand Binding}

Striatum, hippocampus, or midbrain regions were rapidly dissected on ice and frozen in liquid nitrogen. $\left[{ }^{3} \mathrm{H}\right] \mathrm{SCH} 23390$ binding to D1 receptors was assessed as 
described previously (Bowden et al, 1997). Briefly, striata were homogenized in $50 \mathrm{mM}$ Tris- $\mathrm{HCl}(\mathrm{pH} 7.4)$, centrifuged, and resuspended twice to remove endogenous dopamine. Membranes were incubated for $1 \mathrm{~h}$ at room temperature in a buffer containing $50 \mathrm{mM}$ Tris- $\mathrm{HCl}(\mathrm{pH} 7.4), 120 \mathrm{mM} \mathrm{NaCl}$, $5 \mathrm{mM} \mathrm{KCl}, 2 \mathrm{mM} \mathrm{CaCl}, 1 \mathrm{mM} \mathrm{MgCl}_{2}, 100 \mathrm{nM}$ ketanserin, and increasing concentrations of the radioligand for saturation analysis. Nonspecific binding was determined with $10 \mu \mathrm{M}$ cis-flupenthixol. Bound ligand was separated from free by rapid filtration onto Whatman GF/C filters washed with ice-cold Tris buffer. Saturation curves were fitted by nonlinear regression using GraphPad Prism software (GraphPad Software Inc., San Diego, CA). $\left[{ }^{3} \mathrm{H}\right]$ quinpirole binding to D2 receptors was assessed similarly (Malmberg and Mohell, 1995); the binding buffer contained $50 \mathrm{mM}$ Tris- $\mathrm{HCl}(\mathrm{pH} 7.4), 120 \mathrm{mM} \mathrm{NaCl}, 1 \mathrm{mM}$ EDTA, $5 \mathrm{mM} \mathrm{KCl}$, and $4 \mathrm{mM} \mathrm{MgCl}_{2}$, and nonspecific binding was determined with $1 \mu \mathrm{M}(+)$-butaclamol. For $\left[{ }^{3} \mathrm{H}\right] \mathrm{CFT}\left(\left[{ }^{3} \mathrm{H}\right]\right.$ WIN 35428$)$ binding (Madras et al, 1989), membranes were incubated for $2 \mathrm{~h}$ on ice in a buffer containing $50 \mathrm{mM}$ Tris- $\mathrm{HCl}(\mathrm{pH} 7.4), 120 \mathrm{mM} \mathrm{NaCl}, 4 \mathrm{nM}$ $\left[{ }^{3} \mathrm{H}\right] \mathrm{CFT}$, and increasing concentrations of cold CFT for homologous competition analysis. Filtration was done using Whatman GF/B filters presoaked in $0.1 \%$ bovine serum albumin. All radioligands were obtained from New England Nuclear/PerkinElmer Life Sciences (Waltham, MA).

\section{Immunohistochemistry}

Mice were given i.p. injections of saline, cocaine $(20 \mathrm{mg} / \mathrm{kg})$, or amphetamine $(3 \mathrm{mg} / \mathrm{kg})$. After $90 \mathrm{~min}$ they were anaesthetized with chloral hydrate $(400 \mathrm{mg} / \mathrm{kg}$, i.p.) and perfused transcardially with $0.9 \%$ saline, followed by $4 \%$ paraformaldehyde in phosphate buffered saline ( $\mathrm{pH} 7.4$ at $4^{\circ} \mathrm{C}$ ). Brains were postfixed for $1-3$ days at $4{ }^{\circ} \mathrm{C}$ and cryoprotected in $10 \%$ sucrose. Free-floating $40 \mu \mathrm{m}$ sections were incubated $24 \mathrm{~h}$ at $4{ }^{\circ} \mathrm{C}$ with the primary antisera anti-DARPP-32 (1:3000, C11521, BD Transduction Laboratories, Bedford, $\mathrm{MA})$ or 2 days at $4{ }^{\circ} \mathrm{C}$ with anti-c-Fos $(1: 5000, \mathrm{Ab}-5$, Oncogene, San Diego, CA) followed by appropriate labeled secondary antibody (Vector Laboratories, Burlingame, CA) for $30 \mathrm{~min}$ at room temperature. Slides were viewed on a laser-scanning Zeiss confocal microscope (LSM-510, Carl Zeiss, Oberkochen, Germany) and the IPLab software for Windows v3.0 was used for image processing and analysis (BioVision Technologies Inc). Strict stereological methods were performed for the assessment of the number of DARPP-32- and c-Fos-positive cells as previously described (Cyr et al, 2005). Four adjacent sections were considered from each animal $(+1.20$ to +1.04 from bregma) and the striatum was divided into its dorsal and ventral parts. Anatomical landmarks such as aspect, size and situation of the anterior commissures, corpus callosum, septum, lateral ventricles, striatum, and nucleus accumben were used to ensure that levels studied were similar within and between groups. The average number of positive cells per section, for both the dorsal and ventral parts of striatum, was from two $0.01 \mathrm{~mm}^{3}(0.5 \times 0.5 \mathrm{~mm} \times 40 \mu \mathrm{m})$ counting areas per hemispheres ( $\times 40$ objective), one systematically placed in the lateral part (half exterior) of the striatum and one in its medial part (half interior). The final estimation of the positive cells number per animal was the average of positive neurons per $\mathrm{mm}^{3}$ sampled in both hemispheres of the four adjacent sections as described above \pm SEM from four mice per groups. All sections were coded and quantitative analyses of specimens were performed without the knowledge of genotypes.

\section{Conditioned Place Preference}

Place preference experiments were conducted in a commercially available apparatus (MED Associates MED-PP-MS, Georgia, VT) using the paradigm described in Medvedev et al (2005). The apparatus had two test chambers that were distinguished by different wall colors and patterns, floor texture, and olfactory cues. Experiments included three phases: preconditioning, conditioning, and testing. During preconditioning, mice were allowed free access for $30 \mathrm{~min}$ to both chambers and the time spent in each chamber was recorded. On the next day, cocaine $(20 \mathrm{mg} / \mathrm{kg}$, i.p.) was injected and mice were placed in the less preferred chamber for $30 \mathrm{~min}$; the following day saline injection was paired with the other chamber. After these 2 conditioning days, test sessions were run in which mice were given free access to both chambers and time spent in each was recorded. This cycle of conditioning and testing was repeated three times to assess the effect of repeated drug exposure. Amphetamine conditioned place preference (CPP) was assessed similarly, except that the conditioning phase consisted of 6 consecutive days during which mice were administered saline or amphetamine $2 \mathrm{mg} / \mathrm{kg}$, i.p. on alternate days. This conditioning was followed by one test session to measure place preference.

\section{Statistical Analysis}

Statistical analysis was performed using GraphPad Prism (GraphPad Software Inc.). Biochemical data are expressed as the means \pm SEM, and were analyzed by Student's $t$-test. Behavioral data are expressed as means \pm SEM, and were analyzed by one-way ANOVA followed by Newman-Keuls test or by Student's $t$-test. For cocaine and amphetamine sensitization experiments, data were analyzed by one-way repeated-measures ANOVA with Newman-Keuls post hoc test. For cocaine CPP, two-way repeated-measures ANOVA was first performed to identify treatment effect, genotype effect, and genotype $\times$ treatment interaction. This was followed by one-way repeated-measures ANOVA within genotype to track the development of CPP, and nonpaired two-tailed $t$-test to compare genotypes on specific treatment days. For amphetamine place preference, two-way repeatedmeasures ANOVA was used to test treatment effect, followed by paired two-tailed $t$-test to test significance of treatment effect for each genotype. Statistical significance was determined by probability values less than 0.05 .

\section{RESULTS}

Glutamate Receptor Levels in Various Brain Regions of NR1-KD Mice

Gene expression of the NR1 subunit in homozygous NR1$\mathrm{KD}$ mice has previously been reported to be $5-10 \%$ of the wild-type levels (Mohn et al, 1999). This characterization 
was extended to determine whether there were regional differences in NMDA receptor level, and whether the levels of other components of glutamate transmission were affected by this mutation. Levels of NMDA receptors in prefrontal cortex, striatum and hippocampus of wild-type and NR1-KD mice were assessed by western blot analysis, and revealed that NR2A and NR2B subunits of the NMDA receptor were also substantially reduced to approximately $10-20 \%$ as a consequence of NR1 deficiency (Figure 1). Normally the NR1 subunit is present in excess and is retained in the ER or rapidly degraded when not assembled with an NR2 subunit (Huh and Wenthold, 1999; Scott et al, 2001). In the NR1-KD mice, the NR1 subunit must be the limiting factor in the assembly of heteromeric NMDA receptors. The results of the western blot analysis showed that NR2 levels are decreased, perhaps as a result of degradation, when NR1 levels are insufficient. No overall changes in AMPA glutamate receptor protein levels were detected by western blot. Total levels of GluR 1 and GluR2/3 subunits appeared unchanged in the striatum, frontal cortex, and hippocampus of NR1-KD mice (Figure 1).

These studies were repeated to measure glutamate receptor levels in the midbrain substantia nigra and ventral tegmental area, where dopaminergic cell bodies are located (Figure 1). As in other brain regions, NR1 protein is present at approximately $10 \%$ of wild-type level, and AMPA receptor subunit GluR1 levels are not altered in NR1-KD mice compared to wild types.

\section{Behavioral Effects of Acute Cocaine and Amphetamine Administration in NR1-KD Mice}

Induction of locomotor hyperactivity is the hallmark behavioral effect of psychostimulants in rodents. Thus, locomotor activity of NR1-KD mice and their wild-type littermates was measured following cocaine administration. Basal locomotor hyperactivity in NR1-KD mice is evident after saline injection, as reported previously (Mohn et al, 1999; Figure 2). Whereas cocaine produced a dosedependent increase in the locomotor activity in wild-type mice, it did not produce a statistically significant increase in NR1-KD mice with doses up to $40 \mathrm{mg} / \mathrm{kg}$ i.p. (Figure 2). Higher doses could not be tested as they rapidly induce seizures in both wild-type and NR1-KD mice. To test whether this observation could be generalized to other psychostimulants, amphetamine was used in a similar paradigm. Amphetamine-induced hyperactivity was comparable between wild-type and NR1-KD mice at a dose of $3 \mathrm{mg} / \mathrm{kg}$, i.p. (Figure 2). These results indicate that the acute behavioral response to cocaine, but not to amphetamine, is severely impaired in NR1-KD mice.

\section{Presynaptic Dopamine Function in the Striatum of NR1- KD Mice}

The basal extracellular levels and turnover of dopamine were previously found to be normal in NR1-KD mice (Mohn et al, 1999); however, psychostimulant-induced increases in dopamine could be altered. To assess this, in vivo microdialysis was performed in the striatum of freely moving mice after the administration of saline, cocaine $(20 \mathrm{mg} / \mathrm{kg}$, i.p.), and amphetamine (3 mg/kg, i.p.). In agreement with the previous study, the basal dialysate concentrations of dopamine were not different between genotypes. Furthermore, there were no significant differences between NR1-KD and wild-type mice in the elevations of extracellular dopamine levels produced by cocaine or amphetamine (Figure 3). In line with these results, the specific binding of the selective cocaine analog $\left[{ }^{3} \mathrm{H}\right] 2$ $\beta$-carbomethoxy-3 $\beta$-(4-fluorophenyl)tropane $\left(\left[{ }^{3} \mathrm{H}\right] \mathrm{CFT}\right.$ ) to the dopamine transporter in striatal membranes was not significantly different between NR1-KD and wild-type mice (Figure 3), indicating that the number and affinity of psychostimulant binding sites and/or dopaminergic nerve terminals are not changed (Soucy et al, 1997). In summary, the differential behavioral effects of cocaine and amphetamine in NR1-KD mice cannot be explained by presynaptic alterations in neurochemical parameters of the dopaminergic system.

\section{Dopamine Receptors in NR1-KD Mice}

Altered expression of NMDA receptors in medium spiny neurons could possibly affect the regulation of postsynaptic D1 and D2 dopamine receptors in the striatum (Scott et al, 2002; Gandolfi and Dall'Olio, 1993; Micheletti et al, 1992), thus modulating the effects of psychostimulants (Xu et al, 1994; Moratalla et al, 1996b; Chausmer and Katz, 2001). This possibility was studied by quantifying receptor levels with radioligand binding, and by measuring the behavioral effects of direct dopamine receptor agonists. The specific binding of D1 receptor radioligand $\left[{ }^{3} \mathrm{H}\right] \mathrm{SCH} 23390$ to striatal membranes is similar in NR1-KD and wild-type mice (Figure 4). Accordingly, the full D1 receptor agonist SKF81297 produces a comparable increase in the locomotor activity of NR1-KD and wild-type mice.

D2 dopamine receptor function was assessed with the D2/ D3 agonist quinpirole. D2 receptor levels measured by radioligand binding with $\left[{ }^{3} \mathrm{H}\right]$ quinpirole are similar in striatal membrane preparations from wild-type and NR1KD mice (Figure 4). Furthermore, no difference in the locomotor effects of the D2 agonist quinpirole was observed between NR1-KD and wild-type mice. Quinpirole inhibited locomotor activity to the same extent (Figure 4), and when the activity is expressed as a percentage of the basal activity, there is no significant difference between wild-type and NR1-KD animals (data not shown).

\section{Biochemical Measures of Postsynaptic Response to Psychostimulants}

Administration of either cocaine or amphetamine induces the expression of the Fos family of transcription factors in the brain (Nestler, 2001; Koob et al, 1998; Graybiel et al, 1990). However, the patterns of induction in the striatum are different, and this has been hypothesized to be due to the differential contribution of the glutamatergic corticostriatal pathway (Moratalla et al, 1996a,b; Graybiel et al, 1990; Tan et al, 2000). To test whether this hypothesis might relate to the observed differential effects of cocaine and amphetamine in NR1-KD mice, we assessed the patterns of c-fos expression after treatment with the two drugs.

Supporting our hypothesis and the behavioral results, amphetamine-induced c-fos protein expression in the 


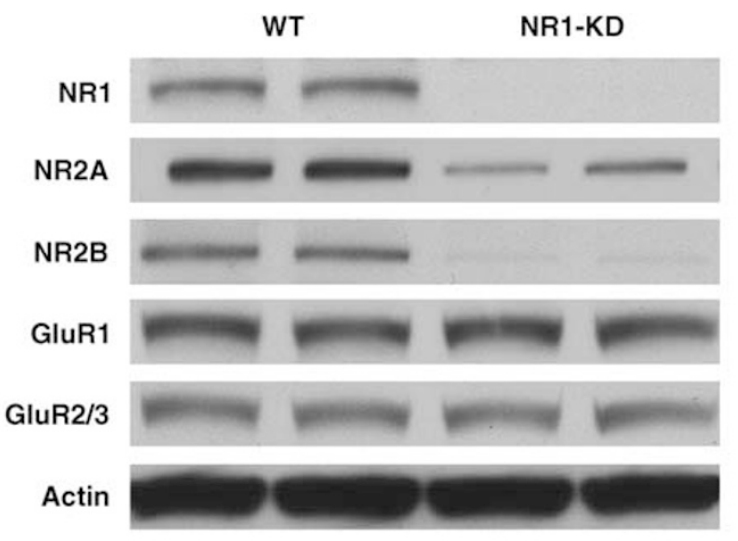

b
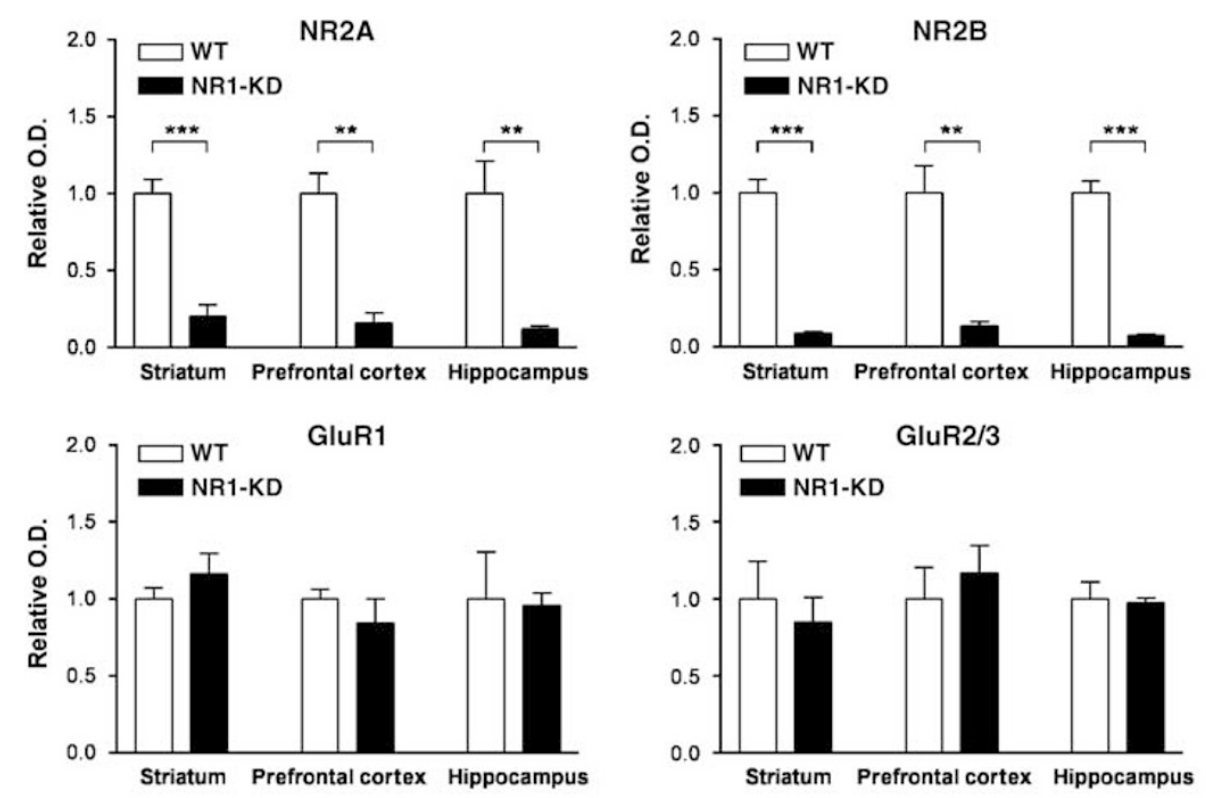

C
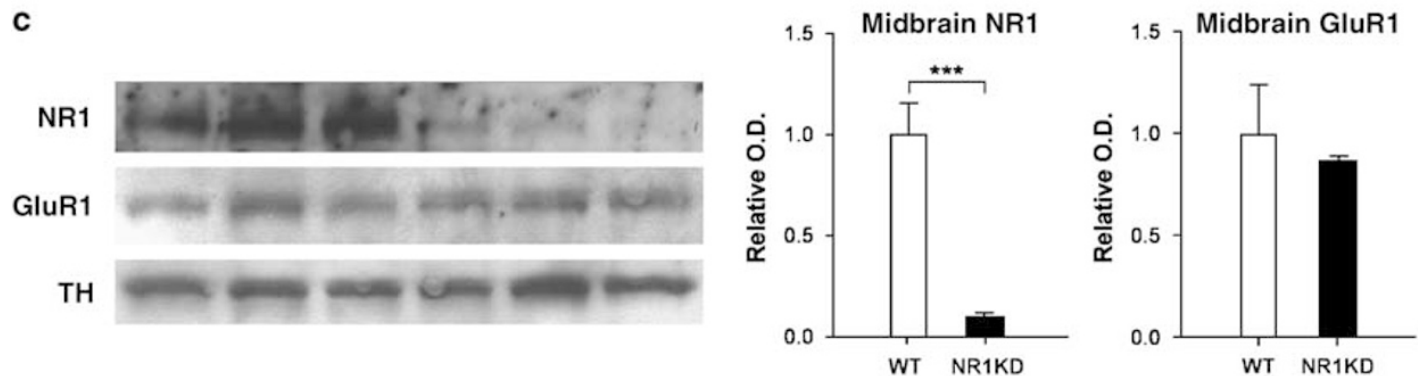

Figure I Protein levels of $N$-methyl-D-aspartic acid (NMDA) and $\alpha$-amino-3-hydroxy-5-methyl-4-isoxazolepropionic acid (AMPA) receptor subunits in NRI-KD mice. (a) Representative western blots of $40 \mu \mathrm{g}$ total protein extracts from the hippocampus of wild-type (WT) and NRI-KD mice. (b) Quantification of glutamate receptor subunit levels in the striatum, prefrontal cortex, and hippocampus measured by densitometry and normalized to actin. NR2A subunit levels in NRI-KD mice are reduced to 19, 16, and 12\% of WT levels in the three brain regions, respectively. NR2B subunit levels are reduced to 9, 14, and 7\% of WT levels in the three brain regions, respectively. Levels of AMPA receptor subunits GluRI and GluR2/3 are unchanged. For each panel, $n=4$ per group, ${ }^{*} * 0<0.0$ I, $* * * * 0.00$ I two-tailed t-test. (c) Protein levels of NRI and GluRI in $50 \mu g$ of midbrain microdissections of substantia nigral ventral tegmentum. Tyrosine hydroxylase (TH) immunoreactivity was used to verify dissection of dopaminergic neurons. Quantification of NRI and GluRI levels measured by densitometry and normalized to TH. NRI subunit is reduced to $9 \%$ in midbrain neurons, and GluRI subunit levels are unchanged ( $p>0.05$, two-tailed t-test).

striatum was similar in NR1-KD and wild-type mice (Figure 5). As reported previously (Moratalla et al, 1996a, b; Graybiel et al, 1990; Tan et al, 2000), cocaine induced c-fos in dorsal and ventral regions of the striatum in wild-type mice (Figure 5). The number of c-fos-positive neurons in ventral striatal regions was not significantly different between the two genotypes. However, the number of neurons with cocaine-induced c-fos expression was significantly lower in the dorsal striatum of NR1-KD mice $(-38 \%)$. Dorsal striatum is related to sensorimotor functions (Heimer et al, 1995) and the difference in this region could explain the different locomotor response to cocaine. 

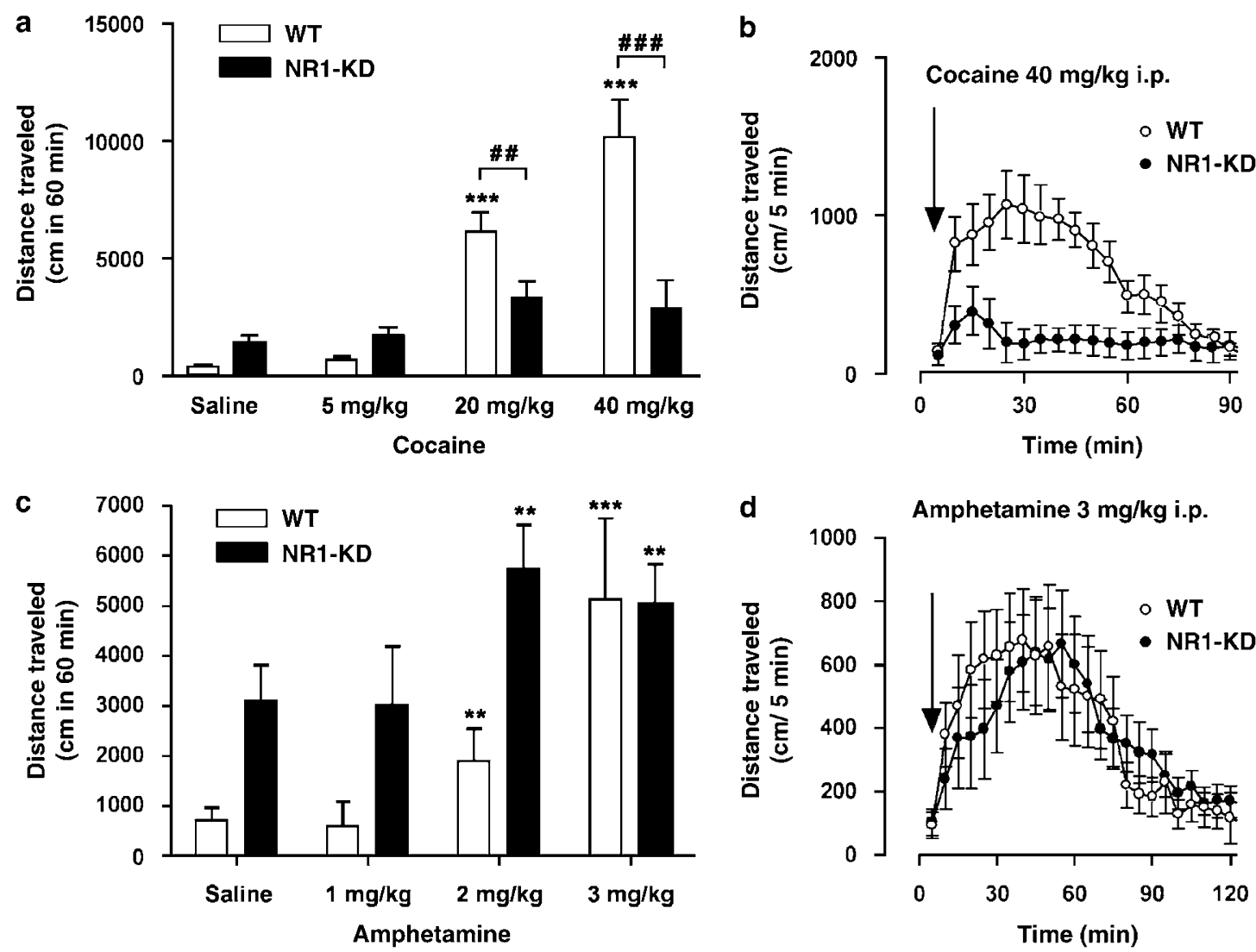

Figure 2 Locomotor-stimulating effects of cocaine and amphetamine in wild-type (WT) and NRI-KD mice. (a) Dose-dependent increase in locomotor activity following treatment with different doses of cocaine was observed in WT, but not NRI-KD mice (saline, $n=20$ per group; cocaine, $n=8$ per group per dose). $* * * * p<0.00$ I compared to saline-treated WT (one-way analysis of variance (ANOVA) followed by Newman-Keuls test), $\wedge p>0.05$ compared to saline-treated NRI-KD (one-way ANOVA followed by Newman-Keuls test). ${ }^{\# \#} p<0.01$ and ${ }^{\# \# \#} p<0.001$ compared to WT mice treated with the same dose (two-tailed t-test). (b) Locomotor activity in WT and NRI-KD mice after treatment with $40 \mathrm{mg} / \mathrm{kg}$ of cocaine ( $n=8$ per group). (c) Dose-dependent increase in locomotor activity following treatment with different doses of amphetamine was seen in both WT and NRI-KD mice (saline, $n=8$ per group: amphetamine, $n=8$ per group per dose). *** $<0.0$ I, **** $p<0.00$ I, compared to saline-treated WT or NRI-KD mice (one-way ANOVA followed by Newman-Keuls test). (d) Locomotor activity in WT and NRI-KD mice after treatment with $3 \mathrm{mg} / \mathrm{kg}$ of amphetamine $(W T, n=8 ; K D, n=9)$.

a

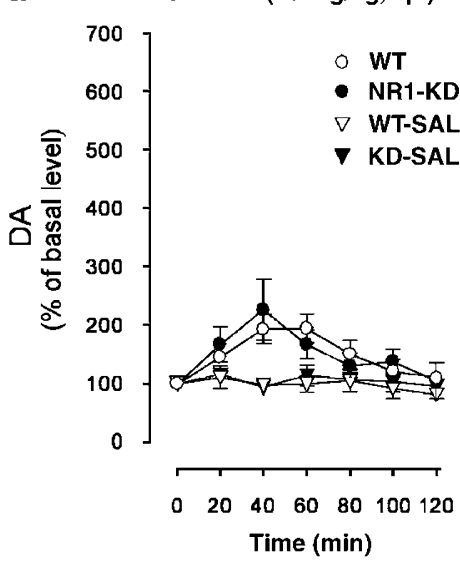

Amphetamine (3 mg/kg, i.p.)

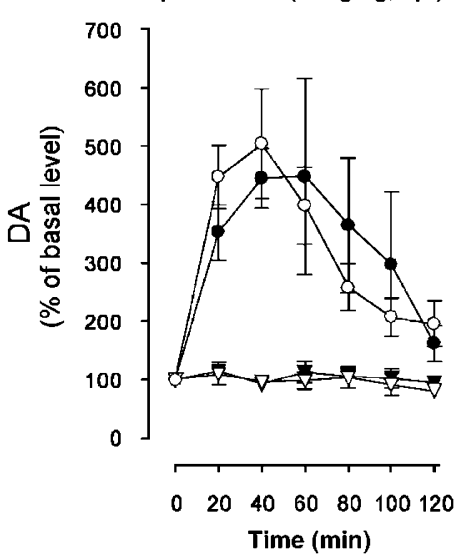

b

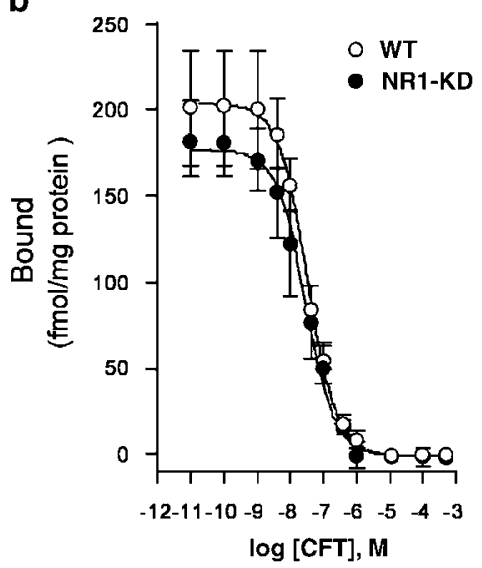

Figure 3 Presynaptic dopamine (DA) function in wild-type (WT) and NRI-KD mice. (a) Effect of cocaine (20 mg/ $/ \mathrm{kg}$, i.p.) and amphetamine (3 mg/kg, i.p.) on extracellular DA levels in striata of WT and NRI-KD mice was measured by in vivo microdialysis in freely moving animals. Effect of saline treatment (WT$\mathrm{SAL}$ and $\mathrm{KD}-\mathrm{SAL}$ ) is presented for comparison (cocaine, $\mathrm{WT} n=6, \mathrm{KD} n=5$; amphetamine, $\mathrm{WT} n=4, \mathrm{KD} n=5 ;$ saline, WT $n=5, \mathrm{KD} n=6$ ). Data are presented as a percentage of the mean of three basal samples collected prior to injection of the drug or saline. Basal dialysate concentrations of DA under present conditions were $41.7 \pm 7.3(n=15)$ and $42.5 \pm 4.6(n=16) \mathrm{fmol} / 20 \mu \mathrm{l}$ for WT and NRI-KD mice, respectively. Cocaine and amphetamine induced elevation of extracellular DA in both genotypes. There were no significant differences in responsiveness to cocaine or amphetamine between genotypes. (b) DA transporter binding in striatal membranes from WT and KD mice measured using $\left.{ }^{3} \mathrm{H}\right] \mathrm{CFT}$ in homologous competition assay (no difference; $n=3$ per group). 

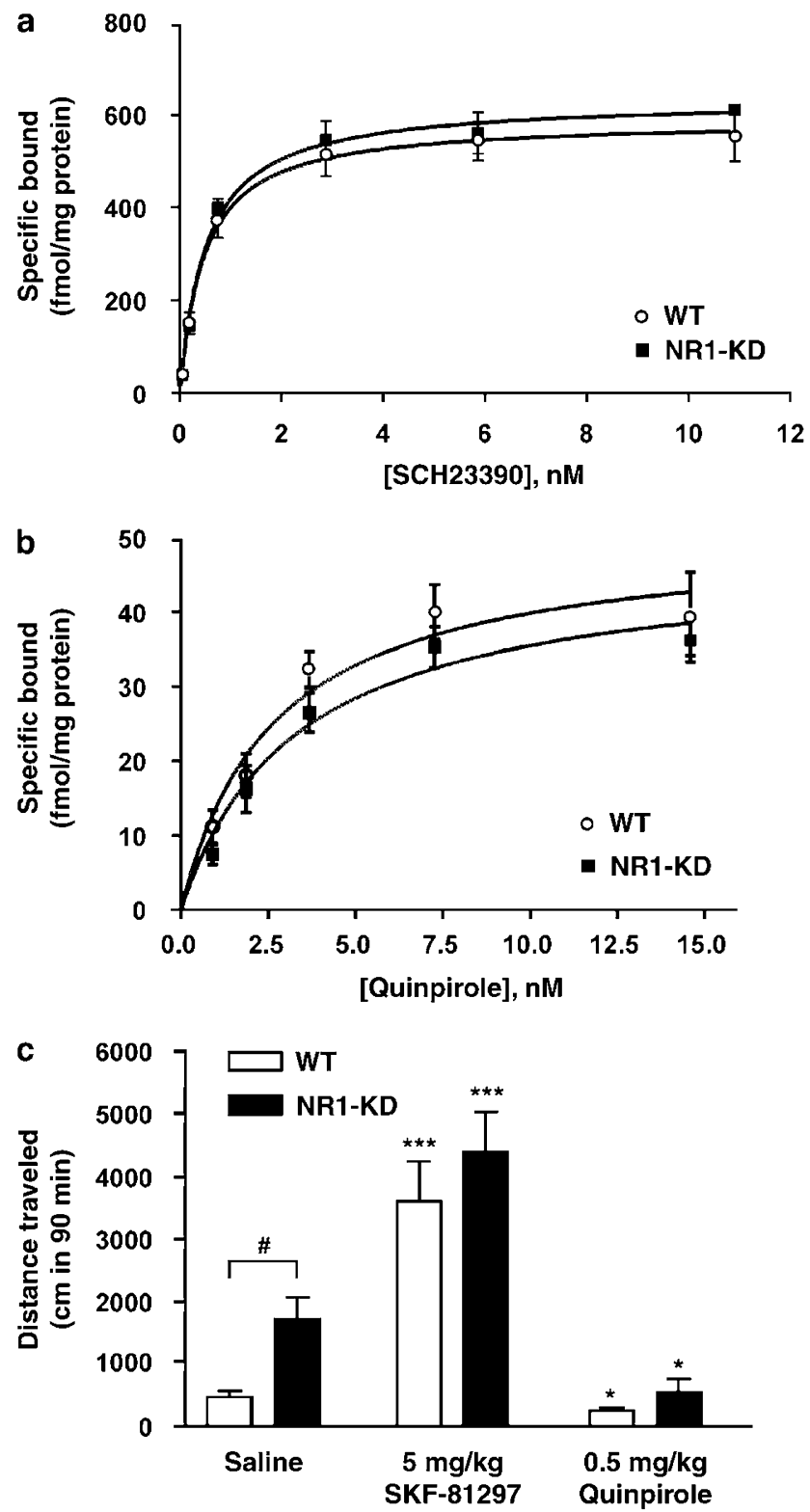

Figure 4 Dopamine receptor biochemistry and behavioral pharmacology. (a) DI dopamine receptor levels, as assessed by $\left[{ }^{3} \mathrm{H}\right] \mathrm{SCH} 23390$ binding to striatal membranes were unchanged in NRI-KD mice $(n=4)$. (b) D2 dopamine receptor levels, as assessed by $\left[{ }^{3} \mathrm{H}\right]$ quinpirole binding to striatal membranes, were unchanged in NRI-KD mice $(n=4)$. (c) Treatment with direct DI receptor agonist SKF-81297 increased locomotor activity in both wild-type (WT) and knockdown (KD) mice (saline, $n=20$; SKF-8|297, $n=8$ ). Treatment with direct D2 receptor agonist quinpirole led to decreased locomotor activity in both WT and KD mice (saline, $n=20$; quinpirole, $n=7$ ). $* p<0.05$, *** $p<0.00$ I compared to saline-treated mice of same genotype (one-way analysis of variance (ANOVA) followed by Newman-Keuls test), ${ }^{*} p<0.05$ compared to saline-treated WT mice (two-tailed $t$-test).

Immunolabeling with anti-DARPP-32 (dopamine- and cAMP-regulated phosphoprotein, $32 \mathrm{kDa}$ ) antibody confirmed that similar numbers of medium spiny neurons were present in NR1-KD and wild-type brains (data not shown) (Greengard, 2001; Anderson and Reiner, 1991), demonstrating that reduced $\mathrm{c}$-fos induction was not a result of decreased neuronal number in NR1-KD mice.
These data provide a biochemical correlate to the differential behavioral effects of cocaine and amphetamine in NR1-KD mice. They also suggest that the activation of the corticostriatal pathway is critical for the stimulatory effects of cocaine, as its ability to induce c-fos expression is diminished in mice with reduced NMDA receptor expression. Although dopamine- and amphetamine-stimulated c-fos expression in the striatum is also affected by NMDA receptor-mediated glutamatergic signaling from the frontal cortex (Konradi et al, 1996; Cenci and Björklund, 1993; Badiani et al, 1998), our results are in line with reports suggesting that amphetamine c-fos induction might be less sensitive to decreased NMDA receptor function (Dalia and Wallace, 1995; Morelli, 1997; Ganguly and Keefe, 2000; Miyamoto S et al, 2004).

\section{Cocaine- and Amphetamine-Induced Sensitization and Conditioned Place Preference in NR1-KD Mice}

Given the reduced acute effects of cocaine in NR1-KD mice, it was of interest to examine the behavioral responses to repeated cocaine exposures. Pharmacological blockade of NMDA receptors has been reported to disrupt the development and expression of behavioral sensitization to the locomotor-stimulant effects of cocaine and other psychostimulants (Vanderschuren and Kalivas, 2000; Wolf, 1998). To assess whether the same occurs in a genetic model of NMDA receptor deficiency, a regimen to induce cocaine sensitization was performed. NR1-KD and wild-type mice were given daily cocaine injections $(20 \mathrm{mg} / \mathrm{kg}$, i.p.) on 5 consecutive days and tested for the locomotor activity on the seventh day using the same dose. Cocaine was administered daily in the same context, the locomotor activity chambers, after a $30 \mathrm{~min}$ habituation period. Drug response was measured both by total distance traveled and by fold activation relative to saline injection to account for differences in basal activity and habituation to the testing apparatus over time.

Wild-type mice already showed full sensitization to cocaine by the third day of cocaine exposure (Figure 6). In NR1-KD mice, however, locomotor responses to cocaine increased modestly until day 7 of the sensitization protocol. On the seventh day of testing, NR1-KD mice showed a diminished response to cocaine as compared to wild-type animals, but a level of sensitization was observed nonetheless. Acquisition of cocaine sensitization in NR1-KD animals was not accompanied by a compensatory increase in striatal NMDA receptor levels (data not shown). These results demonstrate that compromised NMDA receptor function leads to delays in the acquisition of a sensitized state and to attenuation of the expression of sensitization.

In contrast, the development of behavioral sensitization to amphetamine was similar in wild-type and NR1-KD mice. Daily administration of $2 \mathrm{mg} / \mathrm{kg}$ amphetamine led to a comparable increase in the fold activation of locomotor response in both genotypes (Figure 7). NR1-KD mice did not show delays in amphetamine sensitization: in fact a significant increase in locomotor response was seen on the second exposure in NR1-KD mice, while this increase did not reach significance until the fourth exposure in wildtype mice. 
a
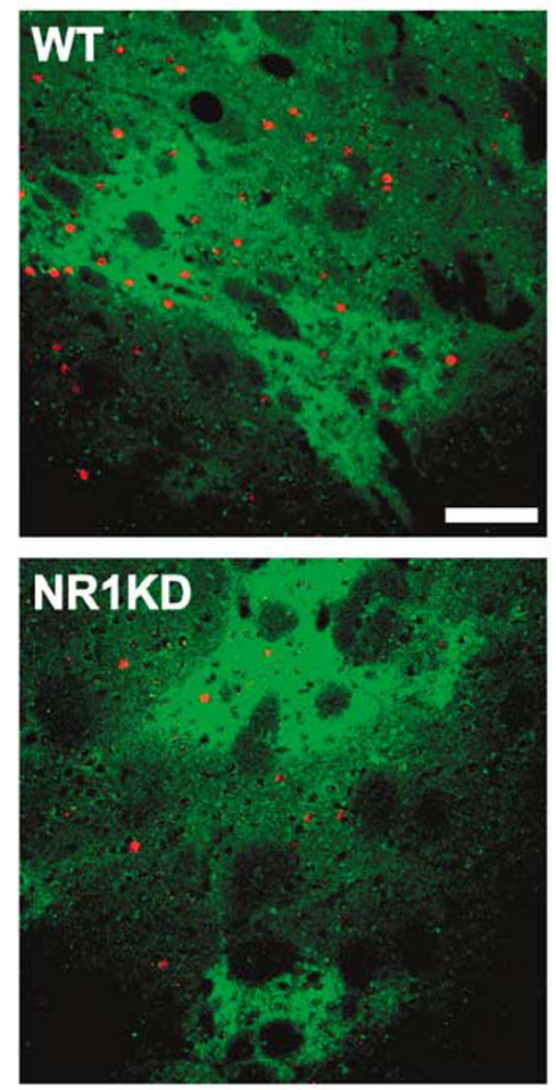

b
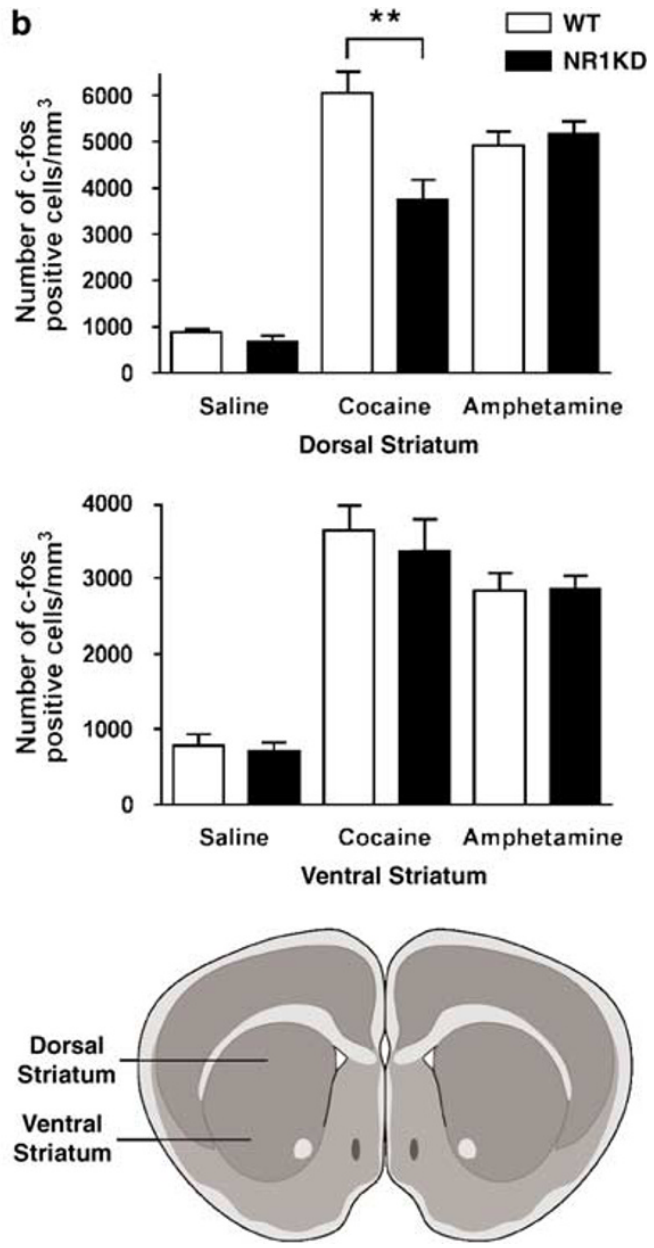

Figure 5 Effects of psychostimulants on c-fos protein expression in wild-type (WT) and NRI-KD mice. (a) Example of the pattern of c-fos expression $90 \mathrm{~min}$ after cocaine treatment $(20 \mathrm{mg} / \mathrm{kg}$, i.p.) in the dorsal part of striatum (+1.20 mm from bregma) of WT and NRI-KD mice. c-Fos-positive nuclei are stained red, and medium spiny neurons belonging to the direct output pathway are stained green using $\mu$-opioid receptor antibody. Scale bar is I00 $\mu \mathrm{m}$. (b) Number of c-fos-positive neurons in dorsal striatum ( +1.20 to $+1.04 \mathrm{~mm}$ from bregma) is significantly lower in NRI-KD mice after cocaine $(20 \mathrm{mg} / \mathrm{kg}$, i.p.) but not amphetamine ( $3 \mathrm{mg} / \mathrm{kg}$, i.p.) treatment, as compared to WT mice ( $n=4$ per group). $* * * 0.0$ I compared to cocaine-treated WT mice (two-tailed t-test). Drawing of coronal slice illustrates region of dorsal and ventral striatum.

To study whether the rewarding properties of cocaine were altered, responses to cocaine $(20 \mathrm{mg} / \mathrm{kg}$, i.p.) in a CPP paradigm were studied (Medvedev et al, 2005). Because NR1-KD mice could eventually become sensitized to the locomotor-stimulating effects of cocaine, the development of CPP was studied over time. During a pretest period, the time spent in each of two chambers was measured, and the less preferred chamber for each mouse was selected for subsequent pairing with cocaine administration. On consecutive days cocaine or saline was paired with a specific chamber, and then on the third day following this pairing, place preference was measured. In accordance with the locomotor activity data, a single injection led to place preference in wild-type mice, whereas NR1-KD mice displayed little place preference at this point (Figure 8a). However, after repeated cocaine injections NR1-KD mice acquired almost the same level of CPP as wild-type mice, in line with our sensitization studies. Our results suggest that while the acute cocaine administration may be less rewarding in NR1-KD mice, repeated administration evokes the eventual development of sensitization and reward in these mice.
$\mathrm{CPP}$ to $2 \mathrm{mg} / \mathrm{kg}$ amphetamine was measured with the same paradigm as with cocaine; however, neither wild-type nor NR1-KD mice displayed CPP when tested in this manner (data not shown). This was likely due to the interruption of conditioning days with test days. When an alternate paradigm was used, with 6 consecutive days of conditioning with alternating amphetamine $(2 \mathrm{mg} / \mathrm{kg})$ and saline, both wild-type and NR1-KD mice displayed significant place preference to the drug-paired chamber (Figure 8b).

\section{DISCUSSION}

In this report, we have used a genetically altered mouse strain to demonstrate that reduced NMDA receptor expression markedly decreases the acute effects of cocaine on behavior and striatal gene expression. In contrast, the effects of another psychostimulant, amphetamine, were generally unchanged. This was somewhat surprising, since both drugs are thought to elicit most of their locomotorstimulant effects through a common mechanism, by 
a

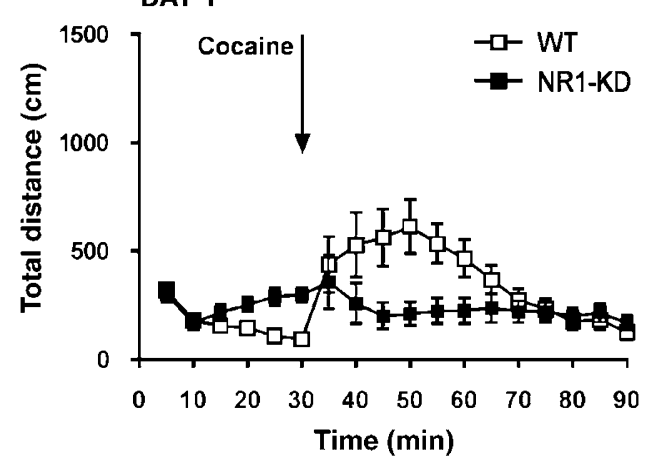

b

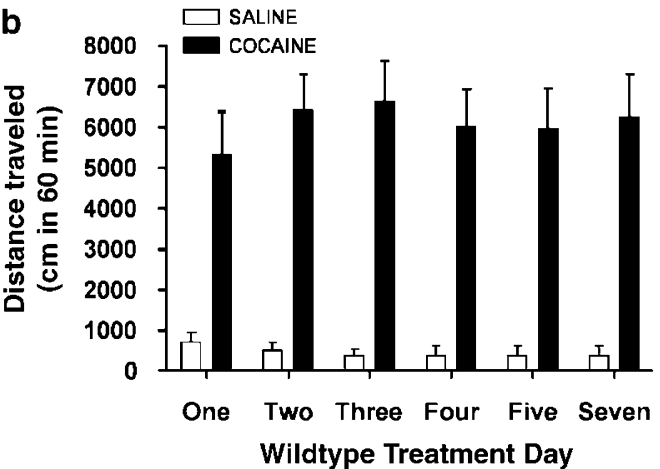

DAY 7
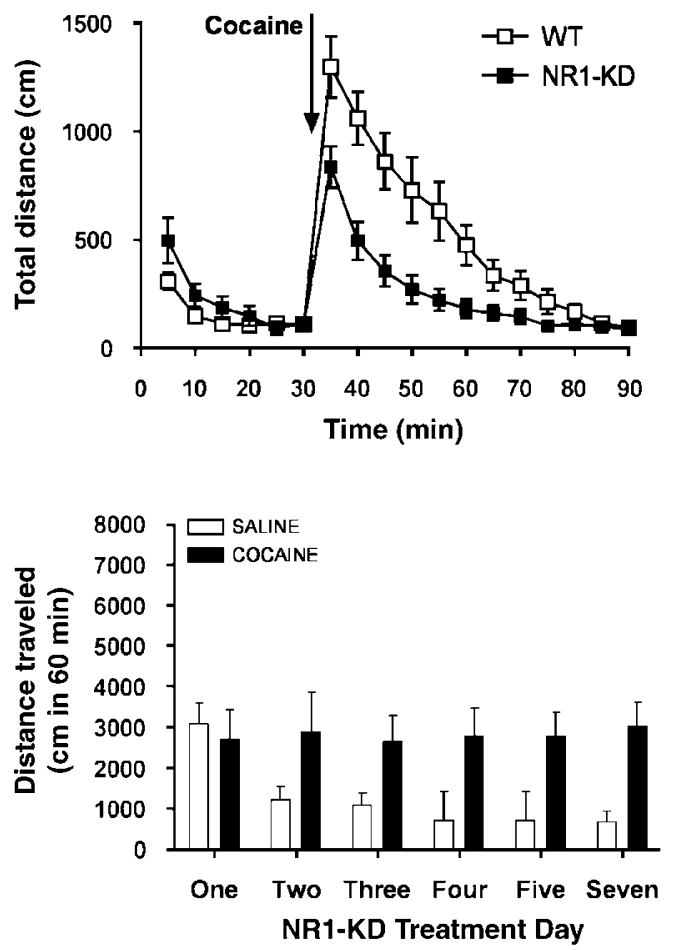

C

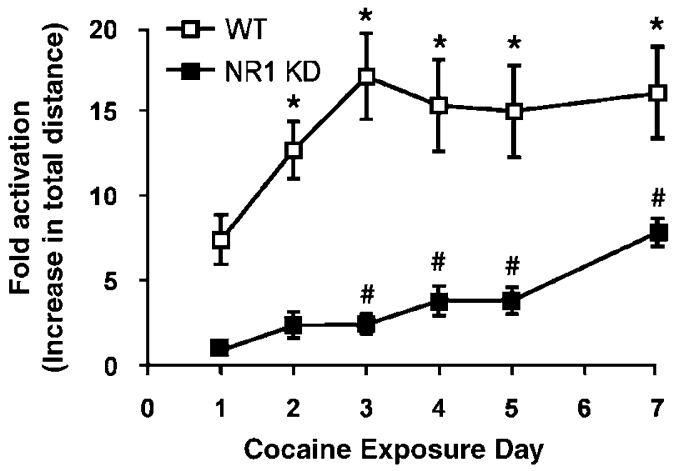

Figure 6 Behavioral sensitization to cocaine. (a) Locomotor response of wild-type (WT) and NRI-KD mice on the first and last day of cocaine sensitization (20 mg/kg, i.p., $n=\mid 4-15$, mean \pm SEM). (b) Sum of locomotor response to cocaine or saline (I h post-injection) during the sensitization paradigm (mean \pm SEM, $n=14-15$ for cocaine, $n=8$ for each genotype for saline). (c) Development of sensitization to cocaine with repeated exposure, expressed as fold activation above saline-treated animals of the same genotype (sum of distance traveled I h post-drug injection divided by sum of distance traveled I h post-saline injection). Analysis by one-way repeated-measures analysis of variance (ANOVA) and Newman-Keuls post hoc test determines that WT mice first show significant increase (above day I) on the second day $\left.{ }^{*} p<0.05\right)$. NRI-KD mice first show significant increase on the third day $\left({ }^{\#} p<0.05\right)$. NRI-KD level of sensitization is reduced on day 7 as compared to that of WT mice (two-tailed t-test, $p<0.00 \mathrm{I}$ ).

increasing extracellular dopamine concentrations in the striatum and nucleus accumbens via blockade or reversal of the dopamine transporter (Amara and Kuhar, 1993; Jones et al, 1998; Sulzer et al, 2005). In addition, behavioral responses to direct dopamine receptor agonists were unaltered, as was the ability of both cocaine and amphetamine to elevate extracellular dopamine in the striatum. The intact behavioral response to direct dopamine receptor agonists in NR1-KD mice provides the opportunity to identify the non-dopaminergic mechanisms essential for full expression of the acute actions of cocaine.

We observed significant reductions in NR2A and NR2B protein levels that resulted from NR1 deficiency. This is consistent with studies performed using mice with a regional deletion of the NR1 gene (Fukaya et al, 2003).
When NR1 deletion was restricted to regions including the CA1 region of the hippocampus, reductions in NR2A and NR2B protein were detected, but message levels from these genes were unchanged. It was suggested that the accumulated NR2 subunits are degraded through intracytosolic degradation by the $26 \mathrm{~S}$ proteasome. It is likely that this phenomenon also explains the global reductions of NR2 subunits that we observe in NR1-KD mice.

The behavioral pharmacology of NMDA receptor-deficient mice underscores the differences in cocaine and amphetamine mechanisms of action. It is known that cocaine's effects on dopamine accumulation are dependent on the firing of dopaminergic neurons (White, 1990), whereas amphetamine's effects are not (Jones et al, 1998). If dopaminergic neurons were firing less in NR1-KD mice, it 
a

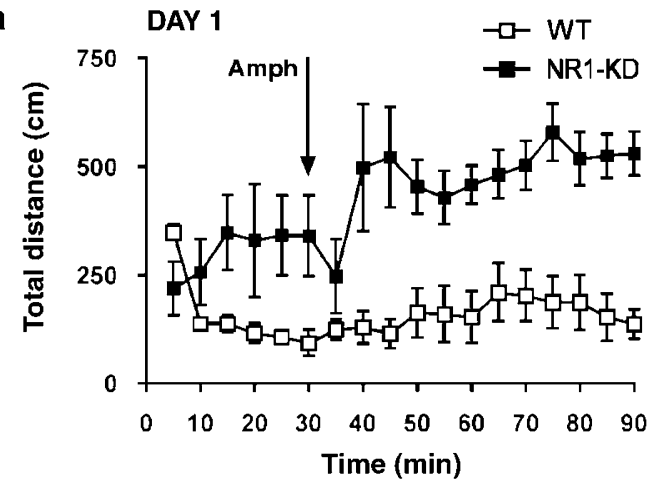

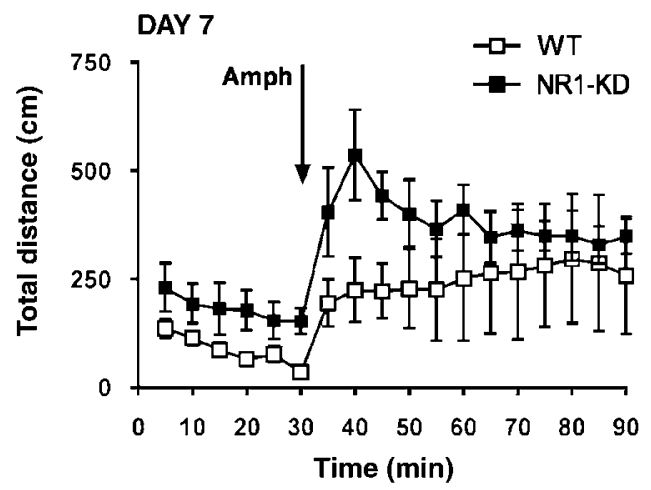

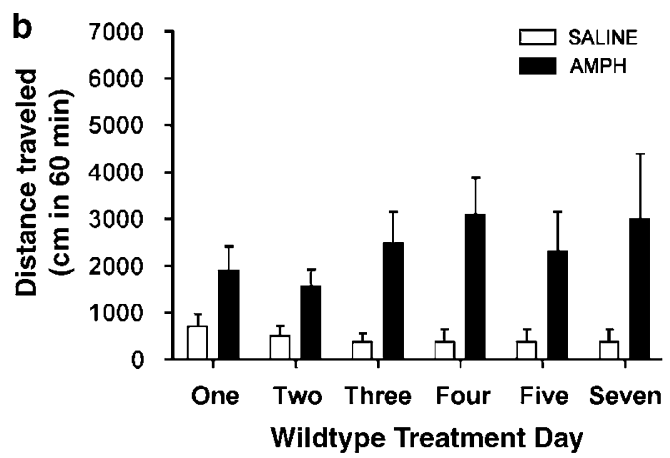

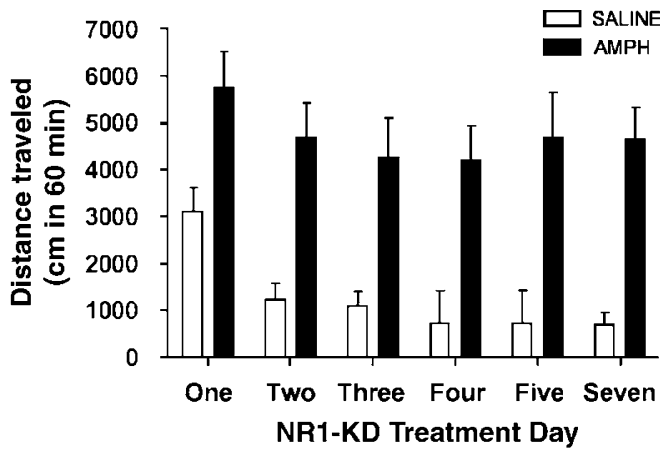

C

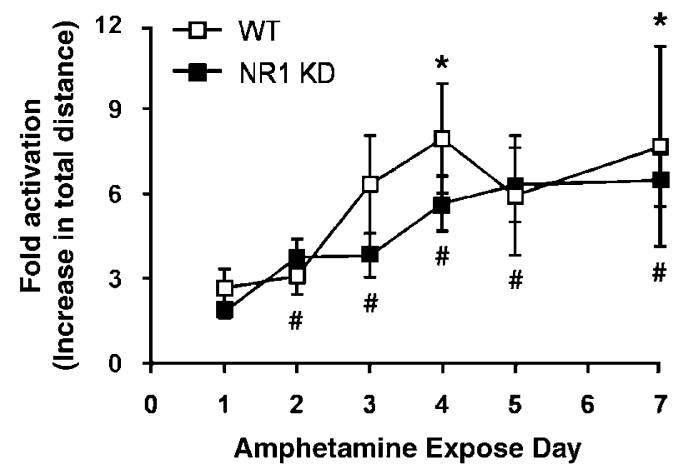

Figure 7 Behavioral sensitization to amphetamine (AMPH). (a) Locomotor response of wild-type (WT) and NRI-KD mice on the first and last day of amphetamine sensitization ( $2 \mathrm{mg} / \mathrm{kg}$, i.p., $n=7-8$, mean \pm SEM). (b) Sum of locomotor response to amphetamine or saline (I h post-injection) during the sensitization paradigm (mean \pm SEM, $n=7-8$ for amphetamine, $n=8$ for each genotype for saline). (c) Development of sensitization to amphetamine with repeated exposure, expressed as fold activation above saline-treated animals of the same genotype (sum of distance traveled I h post-drug injection divided by sum of distance traveled I h post-saline injection). Analysis by one-way repeated-measures analysis of variance (ANOVA) and Newman-Keuls post hoc test determines that WT mice first show significant increase (above day I) on the fourth day $(* p<0.05)$. NRI-KD mice first show significant increase starting from the second day $\left({ }^{\#} p<0.05\right)$

would explain the differential effects of cocaine and amphetamine. This is not indicated by our results, however, which show that extracellular dopamine levels are similar in wild-type and mutant mice at basal levels and that cocaine elicits similar increases in extracellular dopamine concentration in wild-type and mutant mice. Measuring the total accumulation of dopamine after drug treatment does not, however, measure the quality of dopaminergic neuron firing. Electrophysiological studies indicate that psychostimulants can induce burst firing of dopamine neurons, which is thought to encode information about the motivational value of a stimulus (Paladini et al, 2001, 2003; Bonci et al, 2003; Schultz, 1998). Differences in chronic effects of cocaine and amphetamine may perhaps reflect a difference in the ability of these two drugs, in NMDA receptordeficient mice, to induce burst firing of dopamine neurons.
With regards to cocaine's acute effects, it is likely that cocaine induces behavioral hyperactivity and striatal immediate early gene expression not only by increasing dopamine levels in the striatal synapses, but also through the activation of the glutamatergic corticostriatal pathway, in response to elevated extracellular levels of dopamine, serotonin, and norepinephrine in the prefrontal cortex (Tzschentke, 2001; Volkow and Fowler, 2000; Porrino and Lyons, 2000; Rocha et al, 1998; Kuczenski et al, 1991). An explanation for amphetamine's relative independence (compared to cocaine) from glutamatergic neurotransmission might be its high efficacy to release dopamine (Figure 3) as well as other monoamines. In this study we demonstrate that at doses that elicit similar levels of locomotor activity amphetamine elevates extracellular dopamine levels 2-3 times more than cocaine. This further 

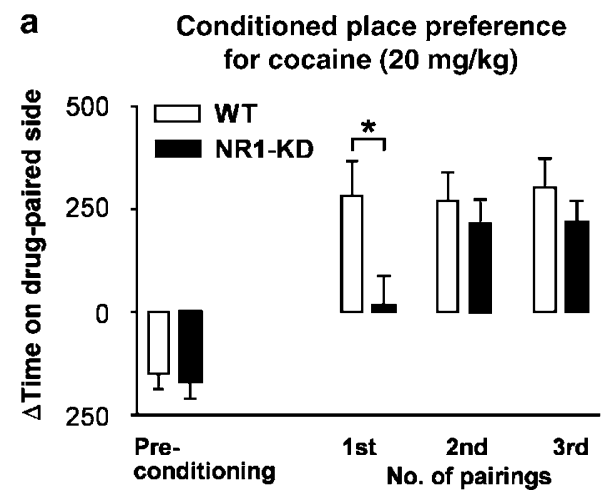

b Conditioned place preference for amphetamine $(2 \mathrm{mg} / \mathrm{kg})$

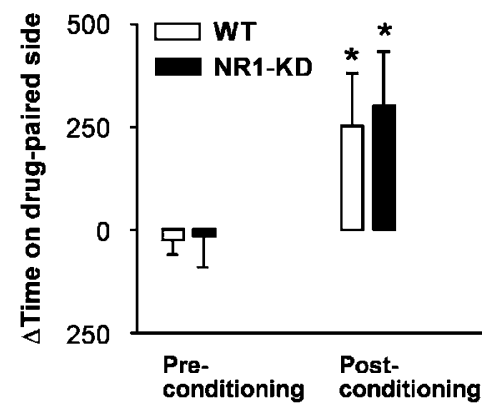

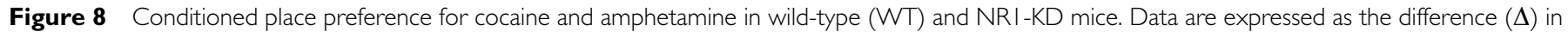
time spent initially (preconditioning) and after drug exposure in the chamber paired with cocaine (20 mg/kg) or amphetamine (2 mg/kg). (a) Cocaine

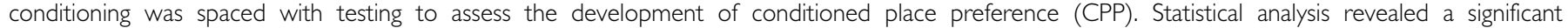

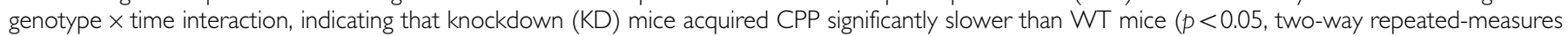

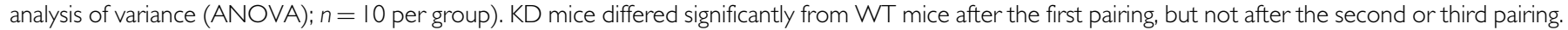

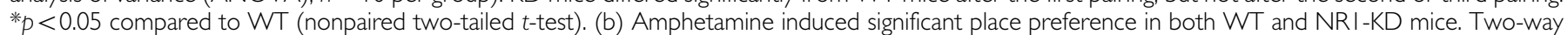

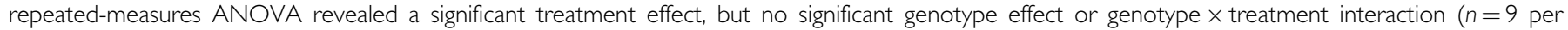

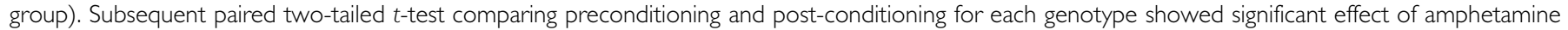
conditioning. $* p<0.05$.

supports the hypothesis of an additional, non-dopaminergic component in the stimulatory effects of cocaine (Kuczenski et al, 1991; Vanderschuren and Kalivas, 2000).

Considering the body of evidence suggesting that blockade of NMDA receptors prevents the development of behavioral sensitization to psychostimulants, the diminished response to repeated administration of cocaine was not completely unexpected (Li et al, 1999; Haracz et al, 1995; Kalivas and Alesdatter, 1993; Stewart and Druhan, 1993; Wolf and Jeziorski, 1993; Heusner and Palmiter, 2005; Miyamoto $\mathrm{Y}$ et al, 2004). More surprising was that some level of sensitization to cocaine still persisted and that amphetamine sensitization developed to the same extent in NR1 mutant animals as in wild types. It should be noted that sensitization to amphetamine for both genotypes was a reflection of the locomotor response to amphetamine relative to the locomotor response to saline, as habituation to the testing environment was observed in both genotypes.

One explanation for the ability of mutant animals to show any level of sensitization is that the remaining $10 \%$ of functional NMDA receptors are sufficient for sensitization to develop in NR1-KD mice. However, low doses of MK-801 $(0.2-0.3 \mathrm{mg} / \mathrm{kg})$ have been reported to disrupt sensitization (Li et al, 1999; Haracz et al, 1995; Kalivas and Alesdatter, 1993; Stewart and Druhan, 1993; Wolf and Jeziorski, 1993, Vanderschuren and Kalivas, 2000; Wolf, 1998). At these doses in vivo, NMDA receptor occupancy and antagonism by MK-801 is only $40-50 \%$ (Price et al, 1988; Murray et al, 2000). Perhaps these results instead illustrate the points of difference and similarity between acute pharmacological NMDA receptor blockade and chronic genetic hypofunction of the NMDA receptor system. NR1 mutant animals have a sustained impairment in NMDA receptor function through development and adulthood, and the composition of the glutamatergic synapse is altered at the time when psychostimulants are first presented. The behavioral consequences of this alteration are most evident in the acute response to cocaine; however, with repeated exposure to cocaine, sensitization does occur, although its acquisition is impaired compared to wild-type mice. The expression of sensitization, measured on the seventh day of the paradigm, is also reduced.

Although deficits in cocaine sensitization were evident in mutant animals, cocaine was still rewarding to NR1-KD mice as demonstrated in the CPP paradigm. Establishment of place preference was, however, delayed in NR1-KD in comparison to wild-type animals. It was not possible to directly compare the development of cocaine and amphetamine with this same paradigm, because the temporal spacing and interruption of drug-paired exposures prevented robust CPP to amphetamine in wild-type animals using the specific design of this paradigm (data not shown). However, using a regimen of consecutive conditioning with alternating amphetamine and saline exposures, it was possible to measure amphetamine CPP, which occurred in wild-type and NR1-KD mice. These studies indicate that chronic NMDA receptor deficiency does not eliminate the rewarding effects of these psychostimulants.

The delay in the development of CPP to cocaine may indicate that the same processes underlying sensitization need to occur before cocaine is experienced as rewarding by NR1-KD mice. Perhaps the repeated elevation of dopamine, which remains intact in NR1-KD mice, can eventually induce equivalent neurochemical changes that cocaine normally elicits through the combination of NMDA receptor and dopamine receptor neurotransmission. An alternative explanation for the delayed performance in the CPP paradigm may be that these mice have difficulties associating environmental cues with the drug, as their spatial memory could be impaired due to decreased number of hippocampal NMDA receptors (Tsien et al, 1996).

In conclusion, the lack of obvious functional deficits in the brain dopamine system of NR1-KD mice strongly suggests a specific role for glutamatergic NMDA receptor signaling in the acute actions of cocaine, making it clearly distinct from another psychostimulant, amphetamine. The substantial loss of acute response to cocaine is in contrast to the more subtle deficits in sensitization and reward. The 
nature of these contrasting phenotypes is such that with NMDA receptor deficient mice we may dissect the contribution of the major neurotransmitter systems at different stages of the pathological progression leading to addiction.

\section{ACKNOWLEDGEMENTS}

We thank Dr Beverly Koller for providing NR1 KD mutant mice. We also thank Julie Harris, Wendy Roberts, and Katherine Clark for excellent technical assistance and Dr Jean Martin Beaulieu for helpful comments. This work was supported in part by a grant from NIH NS19576 (to MGC), NIDA DA02749 (to LAD) and NIDA DA017703 (to AJR). AL was supported in part by Academy of Finland. MC and AS were holders of Fonds de Recherche en Sante du Quebec fellowship, and AS is supported by CIHR.

\section{DISCLOSURE/CONFLICT OF INTEREST}

MGC receives compensation as a member of the Scientific Advisory Board of Acadia Pharmaceutical and owns stock in the company. He has consulted for Lundbeck and has received compensation. He has also received compensation in the form of honoraria for lecturing at various scientific meetings and academic institutions. None of the above presents any conflicts of interest with the results being described in the present paper.

\section{REFERENCES}

Amara SG, Kuhar MJ (1993). Neurotransmitter transporters: recent progress. Annu Rev Neurosci 16: 73-93.

Anderson KD, Reiner A (1991). Immunohistochemical localization of DARPP-32 in striatal projection and striatal interneurons: implications for the localization of D1-like dopamine receptors on different types of striatal neurons. Brain Res 568: 235-243.

Badiani A, Oates MM, Day HE, Watson SJ, Akil H, Robinson TE (1998). Amphetamine-induced behavior, dopamine release, and c-fos mRNA expression: modulation by environmental novelty. J Neurosci 18: 10579-10593.

Beattie EC, Carroll RC, Xiang Y, Morishits W, Yasuda H, von Zastrow $\mathrm{M}$ et al (2000). Regulation of AMPA receptor endocytosis by a signaling mechanism shared with LTD. Nat Neurosci 3: 1291-1300.

Beurrier C, Malenka RC (2002). Enhanced inhibition of synaptic transmission by dopamine in the nucleus accumbens during behavioral sensitization to cocaine. J Neurosci 22: 5817-5822.

Bibb JA, Chen J, Taylor JR, Svenningsson P, Nishi A, Snyder GL et al (2001). Effects of chronic exposure to cocaine are regulated by the neuronal protein Cdk5. Nature 410: 376-380.

Bonci A, Bernardi G, Grillner P, Mercuri NB (2003). The dopamine-containing neuron: maestro or simple musician in the orchestra of addiction? Trends Pharmacol Sci 24: 172-177.

Bowden C, Theodorou AE, Cheetham SC, Lowther S, Katona CL, Crompton MR et al (1997). Dopamine D1 and D2 receptor binding sites in brain samples from depressed suicides and controls. Brain Res 752: 227-233.

Cenci MA, Björklund A (1993). Transection of corticostriatal afferents reduces amphetamine- and apomorphine-induced striatal Fos expression and turning behaviour in unilaterally 6-hydroxydopamine-lesioned rats. Eur J Neurosci 5: 1062-1070.
Chausmer AL, Katz JL (2001). The role of D2-like dopamine receptors in the locomotor stimulant effects of cocaine in mice. Psychopharmacology 155: 69-77.

Cyr M, Caron MG, Johnson GA, Laakso A (2005). Magnetic resonance imaging at microscopic resolution reveals subtle morphological changes in a mouse model of dopaminergic hyperfunction. Neuroimage 26: 83-90.

Dalia A, Wallace LJ (1995). Amphetamine induction of c-fos in the nucleus accumbens is not inhibited by glutamate antagonists. Brain Res 694: 299-307.

Ehlers MD (2000). Reinsertion or degradation of AMPA receptors determined by activity-dependent endocytic sorting. Neuron 28: 511-525.

Fukaya M, Kato A, Lovett C, Tonegawa S, Watanabe M (2003). Retention of NMDA receptor NR2 subunits in the lumen of endoplasmic reticulum in targeted NR1 knockout mice. Proc Natl Acad Sci USA 100: 4855-4860.

Gainetdinov RR, Wetsel WC, Jones SR, Levin ED, Jaber M, Caron MG (1999). Role of serotonin in the paradoxical calming effect of psychostimulants on hyperactivity. Science 283: 397-401.

Gandolfi O, Dall'Olio R (1993). Chronic treatment with MK-801 decreases D2 dopamine receptor function in rat striatum. Pharmacol Biochem Behav 44: 683-687.

Ganguly A, Keefe KA (2000). Effects of MK-801 on D1 dopamine receptor-mediated immediate early gene expression in the dopamine-depleted striatum. Brain Res 871: 156-159.

Graybiel AM, Moratalla R, Robertson HA (1990). Amphetamine and cocaine induce drug-specific activation of the $\mathrm{c}$-fos gene in striosome-matrix compartments and limbic subdivisions of the striatum. Proc Natl Acad Sci USA 87: 6912-6916.

Greengard P (2001). Neurobiology of slow synaptic transmission. Science 294: 1024-1030.

Haracz JL, Belanger SA, MacDonall JS, Sircar R (1995). Antagonist of $N$-methyl-D-aspartate receptors partially prevent the development of cocaine sensitization. Life Sci 57: 2347-2357.

Heimer L, Zahm DS, Alheid GF (1995). Basal ganglia.In: Paxinos G (ed). The Rat Nervous System,2nd edn. Academic Press: San Diego. pp 579-628.

Heusner CL, Palmiter RD (2005). Expression of mutant NMDA receptors in dopamine D1 receptor-containing cells prevents cocaine sensitization and decreases cocaine preference. J Neurosci 25: 6651-6657.

Huh KH, Wenthold RJ (1999). Turnover analysis of glutamate receptors identifies a rapidly degraded pool of the $N$-Methyl-Daspartate receptor subunit, NR1, in cultured cerebellar granule cells. J Biol Chem 274: 151-157.

Hyman SE, Malenka RC (2001). Addiction and the brain: the neurobiology of compulsion and its persistence. Nat Rev Neurosci 2: 695-703.

Jones SR, Gainetdinov RR, Wightman RM, Caron MG (1998). Mechanisms of amphetamine action revealed in mice lacking the dopamine transporter. J Neurosci 18: 1979-1986.

Kalivas PW, Alesdatter JE (1993). Involvement of $N$-methyl-Daspartate receptor stimulation in the ventral tegmental area and amygdala in behavioral sensitization to cocaine. J Pharmacol Exp Ther 267: 486-495.

Karler R, Calder LD (1992). Excitatory amino acids and the actions of cocaine. Brain Res 582: 143-146.

Karler R, Calder LD, Chaudhry IA, Turkanis SA (1989). Blockade of 'reverse tolerance' to cocaine and amphetamine by MK-801. Life Sci 45: 599-606.

Kenny PJ, Markou A (2004). The ups and downs of addiction: role of metabotropic glutamate receptors. Trends Pharmacol Sci 25: 265-272.

Konradi C, Leveque JC, Hyman SE (1996). Amphetamine and dopamine-induced immediate early gene expression in striatal neurons depends on postsynaptic NMDA receptors and calcium. J Neurosci 16: 4231-4239. 
Koob GF, Sanna PP, Bloom FE (1998). Neuroscience of addiction. Neuron 21: 467-476.

Kuczenski R, Segal DS, Aizenstein ML (1991). Amphetamine, cocaine, and fencamfamine: relationship between locomotor and stereotypy response profiles and caudate and accumbens dopamine dynamics. J Neurosci 11: 2703-2712.

Li Y, Hu XT, Berney TG, Vartanian AJ, Stine CD, Wolf ME et al (1999). Both glutamate receptor antagonists and prefrontal cortex lesions prevent induction of cocaine sensitization and associated neuroadaptations. Synapse 34: 169-180.

Madras BK, Spealman RD, Fahey MA, Neumeyer JL, Saha JK, Milius RA (1989). Cocaine receptors labeled by [3H]2 betacarbomethoxy-3 beta-(4-fluorophenyl)tropane. Mol Pharmacol 36: $518-524$.

Malmberg A, Mohell N (1995). Characterization of [3H]quinpirole binding to human dopamine D2A and D3 receptors: effects of ions and guanine nucleotides. J Pharmacol Exp Ther 274: 790-797.

Medvedev IO, Gainetdinov RR, Sotnikova TD, Bohn LM, Caron MG, Dykstra LA (2005). Characterization of conditioned place preference to cocaine in congenic dopamine transporter knockout female mice. Psychopharmacology 180: 408-413.

Micheletti G, Lannes B, Haby C, Borrelli E, Kempf E, Warter JM et al (1992). Chronic administration of NMDA antagonists induces D2 receptor synthesis in rat striatum. Brain Res Mol Brain Res 14: 363-368.

Miyamoto S, Snouwert JN, Koller BH, Moy SS, Lieberman JA, Duncan GE (2004). Amphetamine-induced Fos is reduced in limbic cortical regions but not in the caudate or accumbens in a genetic model of NMDA receptor hypofunction. Neuropsychopharmacology 29: 2180-2188.

Miyamoto Y, Yamada K, Nagai T, Mori H, Mishina M, Furukawa H et al (2004). Behavioural adaptations to addictive drugs in mice lacking the NMDA receptor epsilon1 subunit. Eur J Neurosci 19: 151-158.

Mohn AR, Gainetdinov RR, Caron MG, Koller BH (1999). Mice with reduced NMDA receptor expression display behaviors related to schizophrenia. Cell 98: 427-436.

Moratalla R, Elibol B, Vallejo M, Graybiel AM (1996a). Networklevel changes in expression of inducible Fos-Jun proteins in the striatum during chronic cocaine treatment and withdrawal. Neuron 17: 147-156.

Moratalla R, Xu M, Tonegawa S, Graybiel AM (1996b). Cellular responses to psychomotor stimulant and neuroleptic drugs are abnormal in mice lacking the D1 dopamine receptor. Proc Natl Acad Sci USA 93: 14928-14933.

Morelli M (1997). Dopamine/glutamate interaction as studied by combining turning behaviour and c-fos expression. Neurosci Biobehav Rev 21: 505-510.

Murray F, Kennedy J, Hutson PH, Elliot J, Huscroft I, Mohnen K et al (2000). Modulation of [3H]MK-801 binding to NMDA receptors in vivo and in vitro. Eur J Pharmacol 397: 263-270.

Nestler EJ (2001). Molecular basis of long-term plasticity underlying addiction. Nat Rev Neurosci 2: 119-128.

Paladini CA, Fiorillo CD, Morikawa H, Williams JT (2001). Amphetamine selectively blocks inhibitory glutamate transmission in dopamine neurons. Nat Neurosci 4: 275-281.

Paladini CA, Robinson S, Morikawa H, Williams JT, Palmiter RD (2003). Dopamine controls the firing pattern of dopamine neurons via a network feedback mechanism. Proc Natl Acad Sci USA 100: 2866-2871.

Porrino LJ, Lyons D (2000). Orbital and medial prefrontal cortex and psychostimulant abuse: studies in animal models. Cereb Cortex 10: 326-333.

Post RM, Rose H (1976). Increasing effects of repetitive cocaine administration in the rat. Nature 260: 731-732.

Price GW, Ahier RG, Middlemiss DN, Singh L, Tricklebank MD, Wong EHF (1988). In vivo labelling of the NMDA receptor channel complex by $\left[{ }^{3} \mathrm{H}\right] \mathrm{MK}-801$. Eur J Pharmacol 158: 279-282.

Ranaldi R, Munn E, Neklesa T, Wise RA (2000). Morphine and amphetamine sensitization in rats demonstrated under moderate- and high-dose NMDA receptor blockade with MK-801 (dizocilpine). Psychopharmacology (Berl) 151: 192-201.

Robinson TE, Kolb B (1997). Persistent structural modifications in nucleus accumbens and prefrontal cortex neurons produced by previous experience with amphetamine. J Neurosci 17: 8491-8497.

Rocha BA, Fumagalli F, Gainetdinov RR, Jones SR, Ator R, Giros B et al (1998). Cocaine self-administration in dopamine-transporter knockout mice. Nat Neurosci 1: 132-137.

Schultz W (1998). Predictive reward signal of dopamine neurons. J Neurophysiol 80: 1-27.

Scott DB, Blanpied TA, Swanson GT, Zhang C, Ehlers MD (2001). An NMDA receptor ER retention signal regulated by phosphorylation and alternative splicing. J Neurosci 21: 3063-3072.

Scott L, Kruse MS, Forssberg H, Brismar H, Greengard P, Aperia A (2002). Selective up-regulation of dopamine D1 receptors in dendritic spines by NMDA receptor activation. Proc Natl Acad Sci USA 99: 1661-1664.

Segal DS, Mandell AJ (1974). Long-term administration of $d$-amphetamine: progressive augmentation of motor activity and stereotypy. Pharmacol Biochem Behav 2: 249-255.

Snyder EM, Colledge M, Crozier RA, Chen WS, Scott JD, Bear MF (2005). Role for A kinase-anchoring proteins (AKAPS) in glutamate receptor trafficking and long term synaptic depression. J Biol Chem 280: 16962-16968.

Soucy JP, Mrini A, Lafaille F, Doucet G, Descarries L (1997). Comparative evaluation of [3H]WIN 35428 and [3H]GBR 12935 as markers of dopamine innervation density in brain. Synapse 25: $163-175$.

Shimizu E, Tang YP, Rampon C, Tsien JZ (2000). NMDA receptordependent synaptic reinforcement as a crucial process for memory consolidation. Science 290: 1170-1174.

Stewart J, Druhan JP (1993). Development of both conditioning and sensitization of the behavioral activating effects of amphetamine is blocked by the non-competitive NMDA receptor antagonist, MK-801. Psychopharmacology (Berl) 110: 125-132.

Sulzer D, Sonders MS, Poulsen NW, Galli A (2005). Mechanisms of neurotransmitter release by amphetamines: a review. Prog Neurobiol 75: 406-433.

Tan A, Moratalla R, Lyford GL, Worley P, Graybiel AM (2000). The activity-regulated cytoskeletal-associated protein Arc is expressed in different striosome-matrix patterns following exposure to amphetamine and cocaine. J Neurochem 74: 2074-2078.

Tang YP, Shimizu E, Dabe GR, Rampon C, Kerchner GA, Zhou M et al (1999). Genetic enhancement of learning and memory in mice. Nature 401: 63-69.

Thomas MJ, Beurrier C, Bonci A, Malenka RC (2001). Long-term depression in the nucleus accumbens: a neural correlate of behavioral sensitization to cocaine. Nat Neurosci 4: 1217-1223.

Tsien JZ, Huerta PT, Tonegawa S (1996). The essential role of hippocampal CA1 NMDA receptor-dependent synaptic plasticity in spatial memory. Cell 87: 1327-1338.

Tzschentke TM (2001). Pharmacology and behavioral pharmacology of the mesocortical dopamine system. Prog Neurobiol 63: 241-320.

Tzschentke TM, Schmidt WJ (1998). Does the noncompetitive NMDA receptor antagonist dizocilpine (MK801) really block behavioural sensitization associated with repeated drug administration? Trends Pharmacol Sci 19: 447-451.

Vanderschuren LJMJ, Kalivas PW (2000). Alterations in dopaminergic and glutamatergic transmission in the induction and expression of behavioral sensitization: a critical review of preclinical studies. Psychopharmacology 151: 99-120.

Volkow ND, Fowler JS (2000). Addiction, a disease of compulsion and drive: involvement of the orbitofrontal cortex. Cereb Cortex 10: $318-325$. 
White FJ (1990). Electrophysiological basis of the reinforcing effects of cocaine. Behav Pharmacol 1: 303-315.

White FJ (2002). A behavioral/systems approach to the neuroscience of drug addiction. J Neurosci 22: 3303-3305.

Wolf ME (1998). The role of excitatory amino acids in behavioral sensitization to psychomotor stimulants. Prog Neurobiol 54: 679-720.

Wolf ME, Jeziorski M (1993). Coadministration of MK-801 with amphetamine, cocaine, or morphine prevents rather than transiently masks the development of behavioral sensitization. Brain Res 613: 291-294.

$\mathrm{Xu} \mathrm{M}, \mathrm{Hu}$ XT, Cooper DC, Moratalla R, Graybiel AM, White FJ et al (1994). Elimination of cocaine-induced hyperactivity and dopamine-mediated neurophysiological effects in dopamine D1 receptor mutant mice. Cell 79: 945-955.

Yao WD, Gainetdinov RR, Arbuckle MI, Sotnikova TD, Cyr M, Beaulieu JM et al (2004). Identification of PSD-95 as a regulator of dopaminemediated synaptic and behavioral plasticity. Neuron 41: 625-638. 